\title{
緩勾配水制域における水边環境の復活と造園の技術的可能性
}

\section{Applicability of Landscape Techniques for Improvement of Riparian Environment in Gentle Slope Section of Tidal River}

\author{
北村 泰一* \\ Hirokazu KITAMURA
}

\begin{abstract}
摘要： 自然災害を受けやすいわが国では，土砂災害・水害に対する安全性を確保しつつ多様な水辺 環境を保全しなければならない。水辺の植生復活に配慮した河川工法として水制工が注目されている が，空中写真の比較判読と現地調查の結果，木曾川下流部の水制域では施工より約 60 年を経た 1975 年以降、治水事業による洪水低隇効果に起因してヤナギ林を主体とする水辺林が形成されたことが明 らかになった。水制域の水辺林は，湿地・干潟・草地・樹林帯など様々な微地形が形成推移する自然 立地的空間であり多様な生物空間を提供しているため，その保全維持管理に果たす造園の技術的可能 性は大きく，関連する河川構造物との有機的連携が必要である。
\end{abstract}

\section{はじめに}

河川流域に扔ける生産活動の拡大や都市化 の進展に伴って水辺環境が著しく変化し，そ の保全と回復が望まれている。すなわち，最 近の動向として，国民生活の安定や向上に伴 い余暇時間が拡大し，快適性（アメニティー） に対する国民の要望が増大したことに起因し て, 溪流, ダム湖，遊水池等の多面的利用に ついてのニーズが高まりつつあり，水辺空間 の効果的な整備が必要とされている。さらに， 河川や水辺の生態系そのものを保全しようと いう要望も強くなってきた。

その一方で，地形が急峻で地質的にも脆弱 であり，降水量が多く特に梅雨期，台風期の 豪雨，冬期の豪雪に集中するといった自然条 件や，国土面積の約 1 割にすぎない沖積平野 に人口の約 5 割, 資産の約 $3 / 4$ が集中し高 度な土地利用が展開されているという社会条 件 ${ }^{9}$ に起因して，わが国は土砂災害や水害な どの自然災害に対する被災ポテンシャルが極 めて高い状態にある。このため，水辺環境整 備を図るにあたっても，土砂災害・水害に対 する安全性を確保したうえで多様な自然環境 を保全し，緑と水が調和した水辺空間を創出 することが要求される。

河川と一言で表現しても，少なくとも山間 部の溪流（以下溪流とする）と平野部を流れ る平地河川に区分が可能で，さらに平地河川 は扇状地付近を流れる中流河川，沖積平野を 流れる下流河川などの区間にも区別できる。 そしてそれぞれの区間では，川幅や水深，河 床勾配, 河床材料などの地形条件が異なって いるため, 土石流や土砂流，洪水流などそれ ぞれの区間で生じる現象の質や規模にも差異 が認められる。ところが，水辺環境整備の現
在の傾向として，例えば瀬・淵を人工的に固 定するなど，平地河川の論理をそのまま渓流 に適用するものが多い。平地河川と溪流との 間には，多様性を創出する因子に違いがあり， 場の条件を無視した画一的な論理・手法で水 辺を固定するのではなく，その場独自の論理 と技術が必要であると思われる。さらにわが 国では，先に述べたような自然条件と社会条 件に起因して，河川が土砂災害・水害の未然 防止を目的とした砂防工事，河川工事の対象 区域となるため，これらの構造物が水辺環境 に与える影響を正しく認識したうえで，水辺 環境の復活を図る必要がある。

これまで筆者は，歴史的に土砂災害・水害 が多発し国土保全事業が進捗する河川を対象 に, 水辺環境保全のあり方について検討して きた。その結果，砂防施設，河川施設の機能 と影響を考慮した水辺環境復活の技術的可能 性と，その中で造園の果たすべき役割につい て，ひとつの示唆が得られたのでここに報告 する次第である。

本研究を進めるにあたり，貴重な資料をご 提供下さいました建設省中部地方建設局木曽 川上流工事事務所, 同木兽川下流工事事務所, ならびに土質資料の分析において有益な助言 を賜った南九州大学造園学科造園工学研究室 高谷精二教授に感謝の意を表します。

\section{1. 研究方法}

1 ) 水辺環境保全をめぐる意識変化

これまで砂防工事に造園手法が応用された 事例として, 広島県厳島の紅葉谷川の砂防工 事 ${ }^{\infty}$ があげられる。紅葉谷川では，昭和 20 年 9 月 17 日に来襲した枕崎台風（吳市で死 者 1,154 名）の豪雨によって崩壊・土石流が
発生し, 土砂磁が下流に流入し厳島神社を埋 没せしめたものである。この災害復旧工事を 実施するに際し，工事対象区域が日本三景の ひとつで瀬戸内海国立公園に位置する史蹟名 勝であるため, 景観保全の観点から多くの制 限と配慮が求められた。すなわち, 巨石・大 小の石材は絶対に傷つけず，割らないで野面 のまま利用する，樹木は伐らない，コンクリー 卜面は眼に触れないよう野面石で包む，等の 基本方針の他，東京大学の丹羽教授（造園学： 当時）らの指導，関係分野からの助言・協力 のもとに砂防工事が進められた。その結果， 自然石をコンクリートで補填した床固工や野 面石で包んだ砂防ダムによって災害復旧を図 ると同時に, 天然の渓流を形造ることによっ て周囲の地形と混然一体となった一大庭園を 作り上げたのである。これは「紅葉谷川庭園 砂防」と呼ばれ, 砂防工事に造園技術が応用 された先駆的事例であり，現在でも砂防河川 での水辺環境整備の方法に大きな影響を与え ている。

環境保全にかかわる住民意識は，経済情勢 や国土利用に対する要望とともに常に変化し 多様化する。すなわち, 第 2 次世界大戦敗戦 後の混乱から復興を経て高度成長期にさしか かる 1945１959 年の間は，ほほ毎年のよう に大型台風や前線豪雨による大水害に見回れ たことから，洪水対策が最優先された時期で あり，紅葉谷川砂防工事が行われたのはまさ にこの時代であった。ところが，1970 年代以 降になると経済偏重政策の反省から水環境へ の関心が高まり，いわゆる「親水」が人々の 関心を集めるようになり，河川環境を総合的 に管理するための「河川環境管理基本計画」 の策定が 1981 年より義務づけられ，1990 年

*南九州大学園芸学部造園学科 
には「『多自然型川づくり』の推進について」 の通達が出され, 多様性に富んだ河川環境の 保全・自然景観の保全に留意した乎法を用い ることが指示されるに至っている。すなわち, 河川敷の緑地利用や景観の保全が主であった 1970 年代から,「川と人とのふれあい」と称 して階段護岸などを利用し単に水辺へのアク セスが要求された 1980 年代を経て, 今日で は生態系の保全・復元にまで大きな関心が寄 せられるようになったと言える。

2 ) 研究方法

（1）河川環境の多梯性を創出する因子 砂防工事や河川工事など，いわゆる河川改 修が水辺環境に及ぼす悪影響として, 蛇行, 瀬・淵の消失による流れの均一化, 護岸工の 建設による岸辺環境の悪化消滅などが挙げら

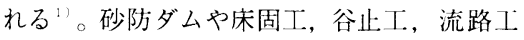
などの配置, あるいは低水護岸による河岸の 補強などによって土砂災害・水害に対する安 全性を高めるという現行の手法の宿命として, そのマイナス面の影響が水辺環境の消失・単 調化, すなわち多様性の衰失という形となっ て顕在化してくる。これは, 砂防工事や河川 工事が進む河川が共通して内包するジレンマ であり, 前述のような水辺環境変化をめぐる 意識変化の中, 単に災害防止だけを目的とす るのではなく, 水辺の動植物の生息に配慮し た計画, 生態系に及ほす影響の少ない工法が 必要になってきたといえる。

河川流域は上流から河口に至るまで，河床 勾配や川幅・水深などの地形条件が場所に応 じて異なり，これが流れの作用や土砂輸送の 形態的な差異となり，流路形態の違いをもた らす。これによって山間を流れる溪流では大 小様々な粒径の石磷の堆積による石䂺空間が, 扇状地・沖積平野を流れる中流域では瀬・淵
の形成変化が, 流れが緩やかになる下流河川 では中州や干潟，ワンド，湿地などの河岸の 微地形が, 多様な水辺環境の創出に大きな役 割を果たす。すなわち，多様性の創出に基本 的な役割を果たす因子が，河川区間によって 異なっているのであり（表-1），本研究で はこうした因子を考慮した水辺環境の復活を 基本的方針とした。

(2) 研究対象区間と研究方法

本研究の刘象としたのは，木曾川と長良川 が瀨割堤によって分流され並流している木曾 川下流部の水制工施工区間である（図-1）。 緩勾配となる下流河川区間では，中州や干 潟, ワンド, 湿地などの河岸の微地形が, 水 辺環境の創出に大きな役割を果たす。従って, こうした微地形の形成要因と時間経過に伴う 推移変化を明らかにすることが, 水辺環境復 活に不可欠となる。本研究では，木曾川下流 部の水制域を対象として, これらの微地形を 中高木林, 草地低木林, 中州 (冠水しないも の), 干潟（高水時に冠水するもの), 池 ·湿 地, 人丁地 (人工改変がなされた高水敷) に 区分し(図－2），1947，1967，1975，1991 年 撮影の空中写真判読からこれらの微地形の時 間的推移を把握した。さらに現地踏查を行い 現況植生を把握するとともに，空中写真判読 結果をもとに形成年代の異なる微地形を抽出 し $10 \mathrm{~m} \times 10 \mathrm{~m}$ の調查地を 10 箇所設けて木本 調査を行い, 侵入木本が時間的な変化ととも にどのように変化していくかを明らかにした。 また, 主要地点での土質特性を調查し解析の 一助とした。

\section{2. 対象地の概要}

北アルプスを源に発し, 流域面積 9,100 $\mathrm{kn}^{2}$, 流路延長 $227 \mathrm{~km}$ を有する木曾川は，わが国を
代表する一級河川である。木曽福島付近で王 滝川と合流した後は深い木曽谷を形成しつつ 南西に流下し, 日本ラインと呼ばれる急流を 経て犬山より濃尾平野に流れている。流域を 構成する地質は, 古生層・中生層 (上流部), 花南岩・流紋岩 (中流部), 第三紀一第四紀 堆積物 (下流部) である。

広大な濃尾平野には木曽川に並行して長良 川, 揖斐川の, いわゆる木曽三川が流下して いる。この三川は, 現在では独立した河川と なっているが, かつては網状に連なり数えき れぬほどの大汇濫を繰り返し, 流路の変遷を 重ねてきた。その原因のひとつに三川の河床 勾配と最高水位発生時刻の違い ${ }^{(4)}$ があり, 濃 尾平野の三川合流点地域一帯に毎年逆流汇濫 が生じていた。このため,「宝暦の治水工事」 (1735 年) など, 古来より治水事業が行われ てきた。1887 年（明治 20）からオランダ人 技師ヨハネス・デ・レーケの指導のもとに, 洪水防御の抜本対策として木曾三川を完全分 流することを中心課題とした明治改修が開始 された。明治改修は 1912 年までの 24 年間に わたって行われ，これによって木曽三川は現 在の流れとなった。この改修以降, 対象区間 においては大規模な改修工事は行われていな い。

\section{3. 水制工と微地形の形成推移}

1) 木曾川治水とケレップ水制

前述のように，木曽川下流部では 1887 年 (明治 20）からオランダ人技師ヨ八ネス・デ. レーケの指導のもとに，洪水防御の抜本対策 として木曾三川を完全分流することを中心課 題とした明治改修が開始された。この改修工 事において, 水制工とよばれる工法が用いら れている。水制工とは，流水を積極的に制御

\section{表一 1 河川区間における水辺環境創出因子の違い}

\begin{tabular}{|c|c|c|c|}
\hline 間 & 下流河川— & $\longrightarrow$ 平地河川 $\longrightarrow$ & 一溪 \\
\hline 地形区分 & テルタ & 沖積平野 & 溪 谷 \\
\hline 河你勾配 & $\sim 1 / 5000$ & $1 / 3000 \sim 1 / 1000$ & $1 / 100 \sim$ \\
\hline 川幅·水深 & 広・深 & & 狒·浅 \\
\hline 河床材料 & 粘十・シルト & 砂 䂺 & 転石·岩盤 \\
\hline 場と力 & 運搬力<是 & 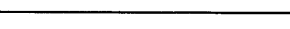 & 運搬力>是 \\
\hline 流れの作用 & 堆 種 & 運搬·堆䅡 & 浸食・運搬 \\
\hline 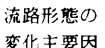 & 潮の干满 & 砂䂺堆の移動 & 石䂺の移動 \\
\hline$\downarrow$ & $\downarrow$ & $\downarrow$ & $\downarrow$ \\
\hline $\begin{array}{l}\text { 多様性の } \\
\text { 荋出要因 }\end{array}$ & $\begin{array}{l}\text { 河岸微地形形成 } \\
\text { 干晹·池・湿地 }\end{array}$ & $\begin{array}{l}\text { 砂喽堆の移動に伴う } \\
\text { 濑・淵の形成 }\end{array}$ & $\begin{array}{l}\text { 石磷の移動に伴う } \\
\text { 石磻空間の形成 }\end{array}$ \\
\hline 国土保全 & 河川・海岸工事 & 河 川 工 事 & 砂防治山工事 \\
\hline
\end{tabular}
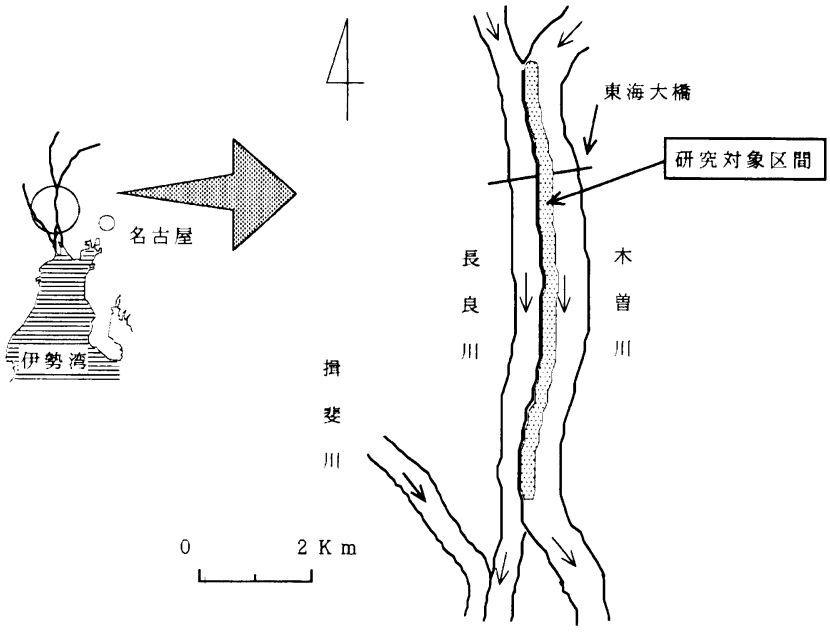

図-1研究対象地の位置 
するために河岸からある角度で河川の中心に 向かって突きだした構造物であり，その主な 機能効果は流速を減少し流向を変化させるこ とによって水制域内での土砂沈激を促し，堤 防や河岸を洗掘から守ることである。水制工 は伝統的な河川工法であり, 河川の底質や洪 水継続時間, 河床勾配, 水深, 流速などに応 じて様々に工夫され, 各地で独自の発展を遂 げているが，木曽川下流で用いられたものは ケレップ水制〉と呼ばれ，そだ沈床を $\mathrm{T}$ 字型 に沈めその上に石張りの覆工を施して仕上げ たものである。覆工の表面部には長軸 $50 \mathrm{~cm}$, 中軸 $30 \mathrm{~cm}$, 短軸 $20 \mathrm{~cm}$ 程度の楕円碟が用いら れ，天端にヤナギ植栽を伴うことから『柳枝 工』とも呼ばれている（写真 $-1 ， 2$ ）。

2 ) 水制域における水辺林復活の過程 水制工の効果によって水制域内での土砂沈 澱が促進されると, 中州や干潟となり,やが ては安定した堆積地へと発達し, 植生侵入が 行われるようになる。木曽川下流部右岸（長 良川と背割堤で接している区間) ではこうし た水制工の効果が顕著に現れたものと考えら れ，様々な種類のヤナギを主体とし，イネ科， カヤツリグサ科などの草本を交えた見事な水 辺林が形成されている (写真-3)。さらに 池や湿地, 干潟なども形成され，鳥類や小動 物にとって良好な生息空間を提供している。 このため, コンクリートに代表される近代河 川工法に対して, 水制工は生物にやさしい伝

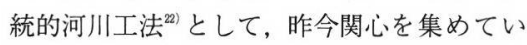
る河川工法で, 河川改修の過程で失われた河 岸植生を復活させる河川工法としての評価が なされている ${ }^{15)}$ なころが,この木曽川下流 部の水制工区間の水辺林が, 水制工の効果と 関連しどのような時間経過のなかで形成され たのか, 意外と知られていない。

図一 3 は, 当該区間を対象に, 1947 年, 1967 年, 1975 年, 1991 年撮影の空中写真か ら地形判読を行い,どのような時間経過のな かで水辺林が形成されたのかを確かめたもの である。ここでは, 草地低木林, 中高木林, 中州・干潟, 池 ·湿地, 人工地 (人工改変が なされた高水敷）に区分した。これによると， 1947 年には水制工の根元付近に既に植生侵 入筒所が認められるが, これは堤防の一部分 である。1967 年になると中州 · 干潟の形成 が進むが, 大きな植生変化は認められない。 ところが, 1975 年になると急速に土砂沈港 による中州・干潟の形成や, 植生侵入, 木本 の生長が進み, 1991 年にはほとんどの箇所 で植生侵入が進んでいるのがわかる。つまり, この区間の水辺林のほとんどは, 1975 年以 降に形成されたものなのである。なお，建設 省木曽川下流工事事務所への聞き达みによれ ば，明治改修以前から存在した樹林を改修の 際に堤防補強に取り入れたものもあると言わ
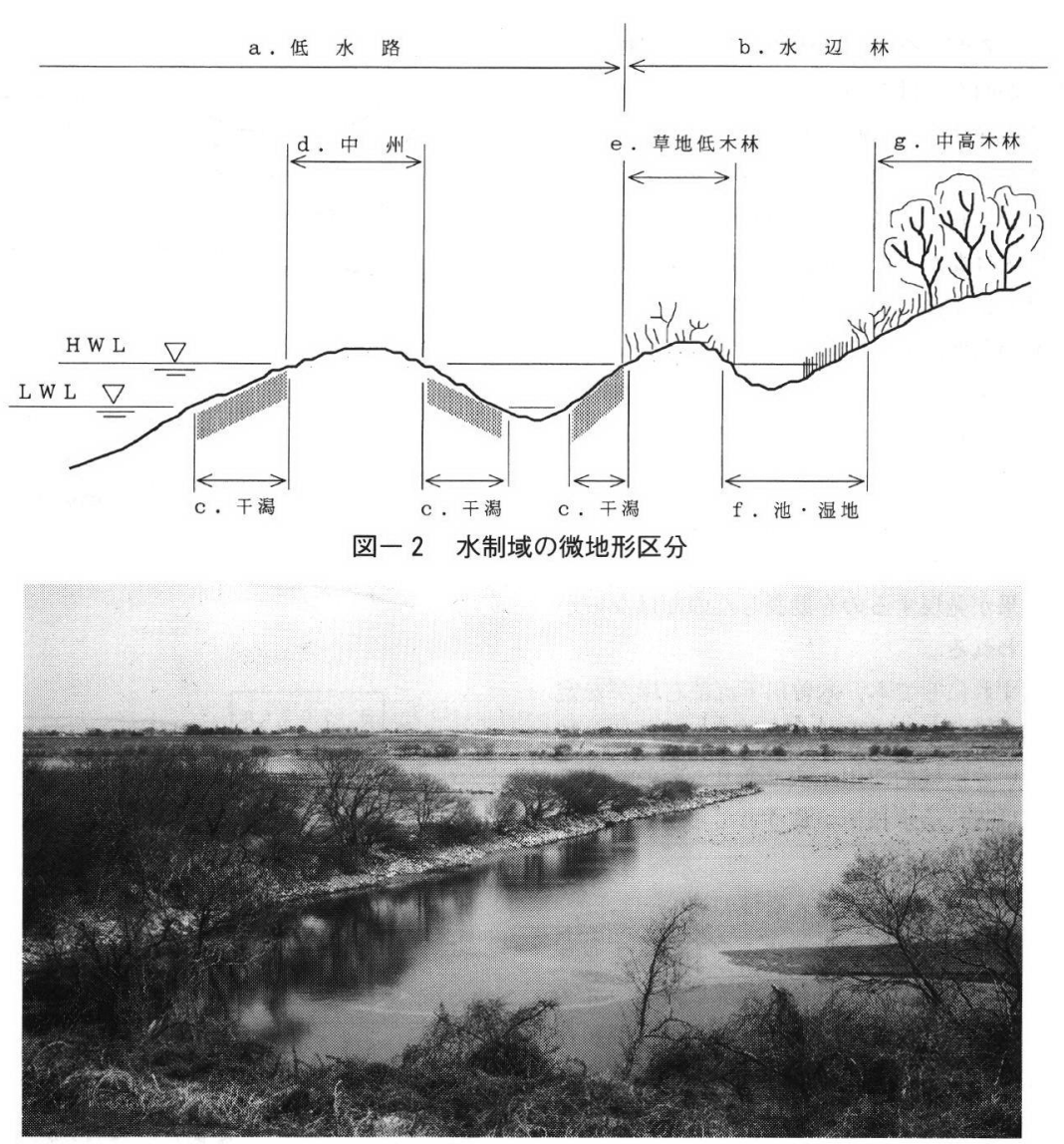

写真一 1 木曽川下流部の水制工

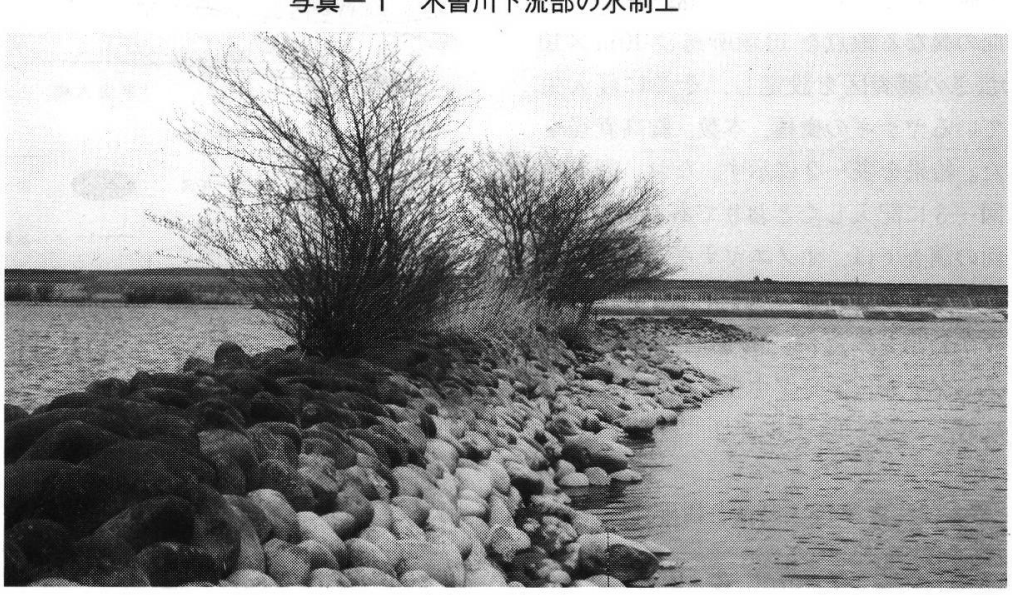

写真一 2 水制工に植栽されたヤナギ

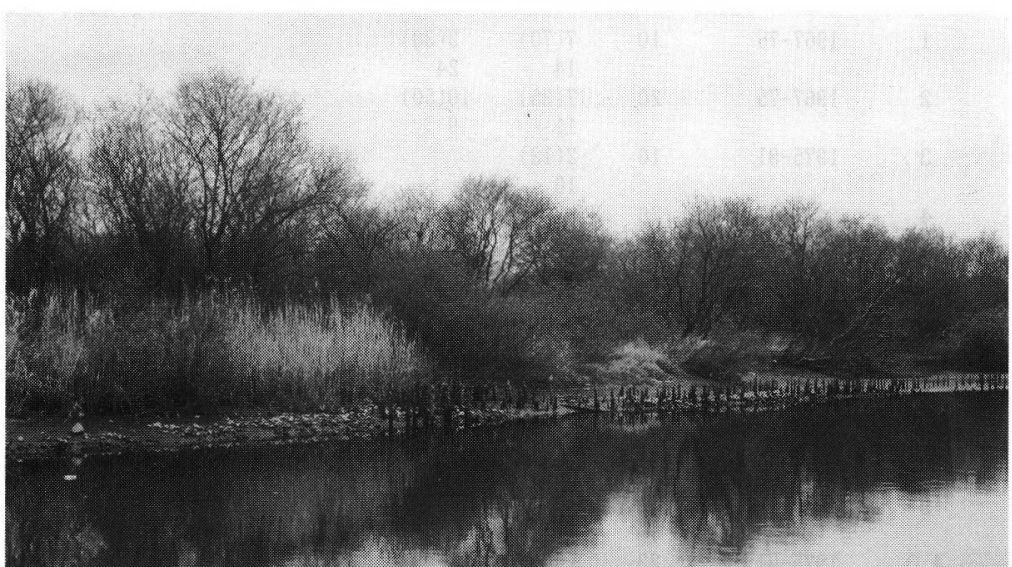

写真－3 水制域の水辺林 
れているが，それが具体的にどの水辺林を指 すのか明かではない。

この区間での水制工が完成したのは，明治 改修が完了した 1912 年であり,その後, 1975 年まで水制工の効果が発現せず土砂沈澱や植 生侵入はなかったのか, あるいは繰り返され る洪水によって中州や干潟，あるいは水辺林 の流出破壊があったのかどうか，定かではな い。しかしながら，1975 年は，木曽川水系に 多目的ダムや洪水対策ダムの竣工が進み洪水 調節容量が急増する時期と一致している とから，水系に展開された洪水対策によって 下流の洪水流量が低減されたことが，水制工 の効果が発現するのを助長したのではないか と思われる。

いずれにしても，木曾川下流部右岸が安定 化し水辺林が形成された直接の要因は，水制 工という伝統的河川工法であり，その効果の 発現は近代治水技術に負うところが大きいと いうことになる。

3) 水制域における侵入樹種の違い

当該区間の水辺林はヤナギを主体とするも のである。中州や干潟などの微地形が出現す ると，ヤナギが速やかに侵入することが知ら れている ${ }^{5)}$ 。こで，位置や侵入時期，地形 に応じて，侵入樹種にどのような違いがある のかを確かめるために，前述の図ー3 から侵 入時期の異なる地点を 10 箇所選び $10 \mathrm{~m} \times 10$ $\mathrm{m}$ の広さの調查区を設定し，そこに侵入生 育しているヤナギの樹種, 本数, 胸高直径を 調べた。結果を表一 2 に示す。なお, 調查地 点は図ー 3 に記入したとおりである。

今回の調查では, オノエヤナギ, シロヤナ ギ, タチヤナギ，コゴメヤナギなど 8 種類の ヤナギが確認されたが, 調査地点(1)（3)で はオノエヤナギ, シロヤナギを主体としてい るのに対し，(5)〜10)では夕チヤナギ，コゴ
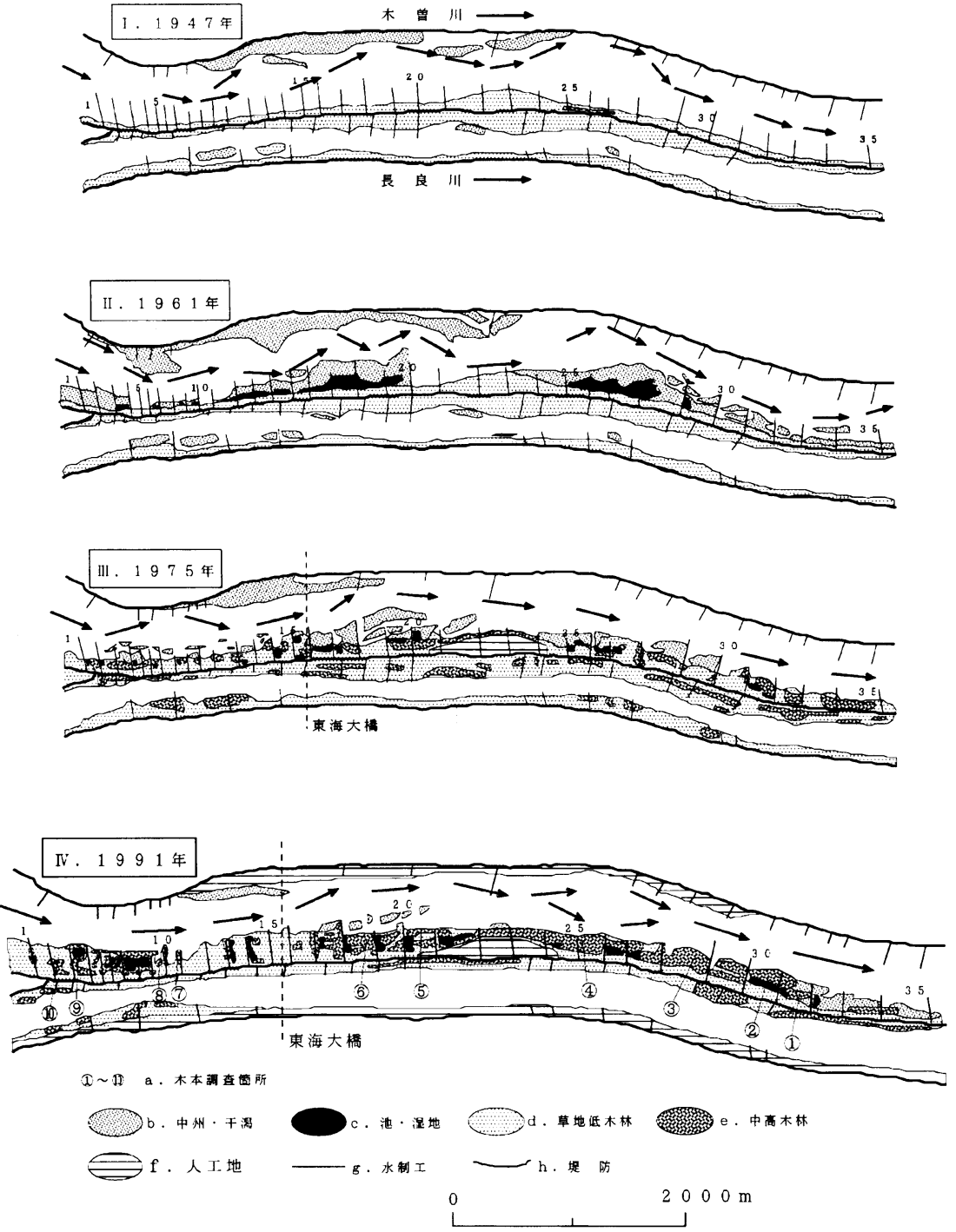

図一3 木曽川下流水制域における水辺成立の過程

\begin{tabular}{|c|c|c|c|c|c|c|c|c|c|c|c|c|}
\hline 調査区域 & 侵入時期 & $\begin{array}{l}\text { 侵入本数 } \\
\left(/ 100 \mathrm{~m}^{2}\right)\end{array}$ & 才ハヤ快゙ & シロヤド゙ & 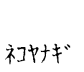 & 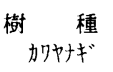 & 抽トギ & 仅コリヤトギ & 多ヤド゙ & コゴ姉キギ & I牛 & 地 形 \\
\hline 1 & $1967-75$ & 10 & $\begin{array}{l}7(70) \\
14\end{array}$ & $\begin{array}{l}3(30) \\
24\end{array}$ & & & & & & & & 湿 \\
\hline 2 & $1967-75$ & 20 & $\begin{array}{l}7(35) \\
11\end{array}$ & $\begin{array}{l}10(50) \\
9\end{array}$ & & & & & $\begin{array}{l}3(15) \\
12\end{array}$ & & & 湿 \\
\hline 3 & $1975-91$ & 16 & $\begin{array}{l}2(12) \\
10\end{array}$ & & $\begin{array}{l}5(31) \\
10\end{array}$ & $\begin{array}{l}3(19) \\
10\end{array}$ & & & $\begin{array}{l}6(38) \\
10\end{array}$ & & & 干潟わき \\
\hline 4 & -1947 & 26 & & & & & & & & & $\begin{array}{c}26(100) \\
10\end{array}$ & 堤防わき \\
\hline 5 & $1947-67$ & 20 & $\begin{array}{l}4(20) \\
12\end{array}$ & $\begin{array}{l}3(15) \\
10\end{array}$ & & & & & $\begin{array}{l}2(10) \\
4\end{array}$ & $\begin{array}{l}11(55) \\
12\end{array}$ & & 湿地 \\
\hline 6 & $1947-67$ & 25 & & $\begin{array}{l}9(36) \\
8\end{array}$ & & & & & & $\begin{array}{l}16(64) \\
15\end{array}$ & & 湿 地 趿 \\
\hline 7 & $1975-91$ & 25 & $\begin{array}{l}3(12) \\
12\end{array}$ & & & & $\begin{array}{l}3(12) \\
7\end{array}$ & & $\begin{array}{l}12(48) \\
7\end{array}$ & $\begin{array}{l}7(28) \\
8\end{array}$ & & 干潟わき \\
\hline 8 & 1975-91 & 7 & & & & & & & $\begin{array}{l}7(100) \\
7\end{array}$ & & & 冠水跡地 \\
\hline 9 & $1975-91$ & 31 & & $\begin{array}{l}1(3) \\
10\end{array}$ & & $\begin{array}{l}18(58) \\
4\end{array}$ & & & $\begin{array}{l}4(13) \\
4\end{array}$ & $\begin{array}{l}8(26) \\
10\end{array}$ & & 沼 \\
\hline 10 & $1975-91$ & 23 & & & & & & $\begin{array}{l}13(57) \\
5\end{array}$ & $\begin{array}{l}3(13) \\
6\end{array}$ & $\begin{array}{l}7(30) \\
9\end{array}$ & & 微 高 地 \\
\hline
\end{tabular}


メヤナギが大半を占めるという侵入樹種の位 置的な違いが恋められた。これを侵入時期と の関連でみると, シロヤナギが 1947 年以前, 及び 1947-1967 年など古い時期に侵入して おり，オノエヤナギが $1967-1975$ 年にその 大半が侵入している。また，夕チヤナギはほ とんどが 1975 年以降に侵入しており，コゴ メヤナギは 1947 年から 1991 年までほぼ永続 的に侵入しているようである。さらにタチヤ ナギが，干潟わきや沼地，冠水跡地など，他 の樹種に比べて水分を多く含んだ簓所に侵入 し生育していることが認められた。

4 ) 微地形と植生

図一 4 は, 人為の影響が比較的少ない東海 大橋の前後付近の現況植生を示したものであ る。水制域では土砂沈殿が進行するにつれて 中州や干潟が形成され，さらに土砂沈殿が進 行すると水域は閉鎖され池や沼地, 湿地へと 変化するようになる。この間に, ヤナギの他, オギ, ツルヨシ, クサヨシなどのイネ科の草 本やカサスゲ, アゼスゲなどのカヤツリグサ 科の草本, カワラサイコ (バラ科), カワラ ケツメイ (マメ科) などの侵入生育が進む。

ここで, 水辺林のうち，1975-1991年に形 成された䇢所 (A-A ' 断面) と, 1947-19 67 年に形成された䇢所 (B-B , 断面) と の植生を, 横断形状との関連で示すと図 -5 のようになる。断面 B-B，では，植生の変 化に応じて土質資料を採取し, 粒度分析, 含 水比・ p H · 電気伝導度の測定も行った。分

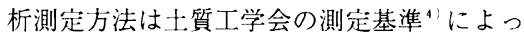
た。

断面 $\mathrm{A}-\mathrm{A}$, は比較的新しい時期に形成さ れたため, 池・沼地が広い部分を占め, 水縁 部にタチヤナギ, ネコヤナギ, カワヤナギが 侵入しており，これらの樹種と比較するとオ ノエヤナギ, コゴメヤナギは水縁部からやや 離れた箇所に生育している。次に断面 $\mathrm{B}-\mathrm{B}$, は断面 $\mathrm{A}-\mathrm{A}$ ’より古い時期に形成された筒 所であり，池や沼地は湿地に変化した箇所で ある。土質特性からみると, 堤防側 ( a ) と 木曽川本流側（f） で粗砂 $(2000 \mathrm{~mm} \sim 420 \mathrm{~mm})$, 細砂 $(420 \mathrm{~mm} \sim 74 \mathrm{~mm})$ を多く含み，水辺林の 中央部ほどシルト $(74 \mathrm{~mm} \sim 50 \mathrm{~mm})$ や粘土（50 $\mathrm{mm} \sim 10 \mathrm{~mm}$ ) の含まれる割合が高くなっている。 ここでも水縁部や湿地にタチヤナギ, カワヤ ナギ, ネコヤナギが侵入し，これらの樹種に 較べてオノエヤナギ，コゴメヤナギ，シロヤ ナギは相対的に水縁部から離れたところに生 育している。さらにタチヤナギやカワヤナギ が相対的に比高の低い位置に生育し, 順次才 ノエヤナギ，コゴメヤナギと相対的に比高の 高い位置に生育しているのが認められた。

この点について各地点の含水比を見てみる と (表一 3 ), 夕チヤナギの侵入しているa 地点と d 地点で 35～40\% と高く，オノエヤ
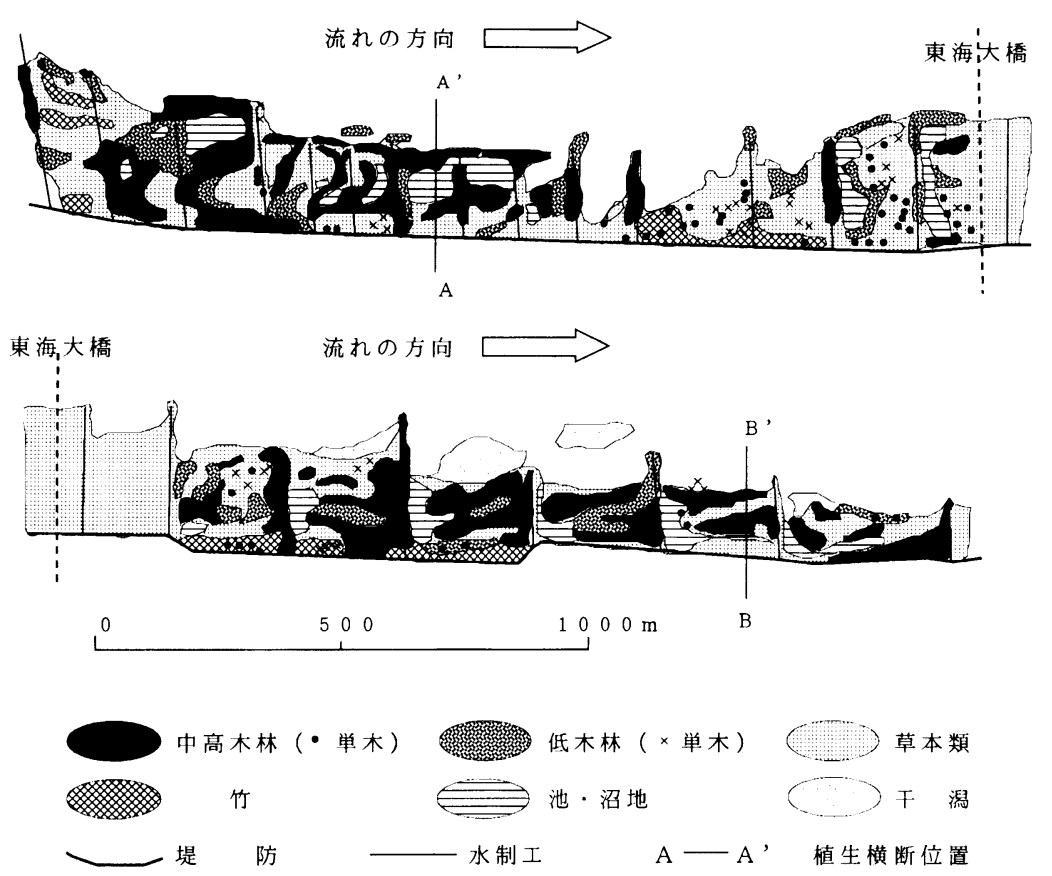

図－4 木曾川下流水制域の現況植生
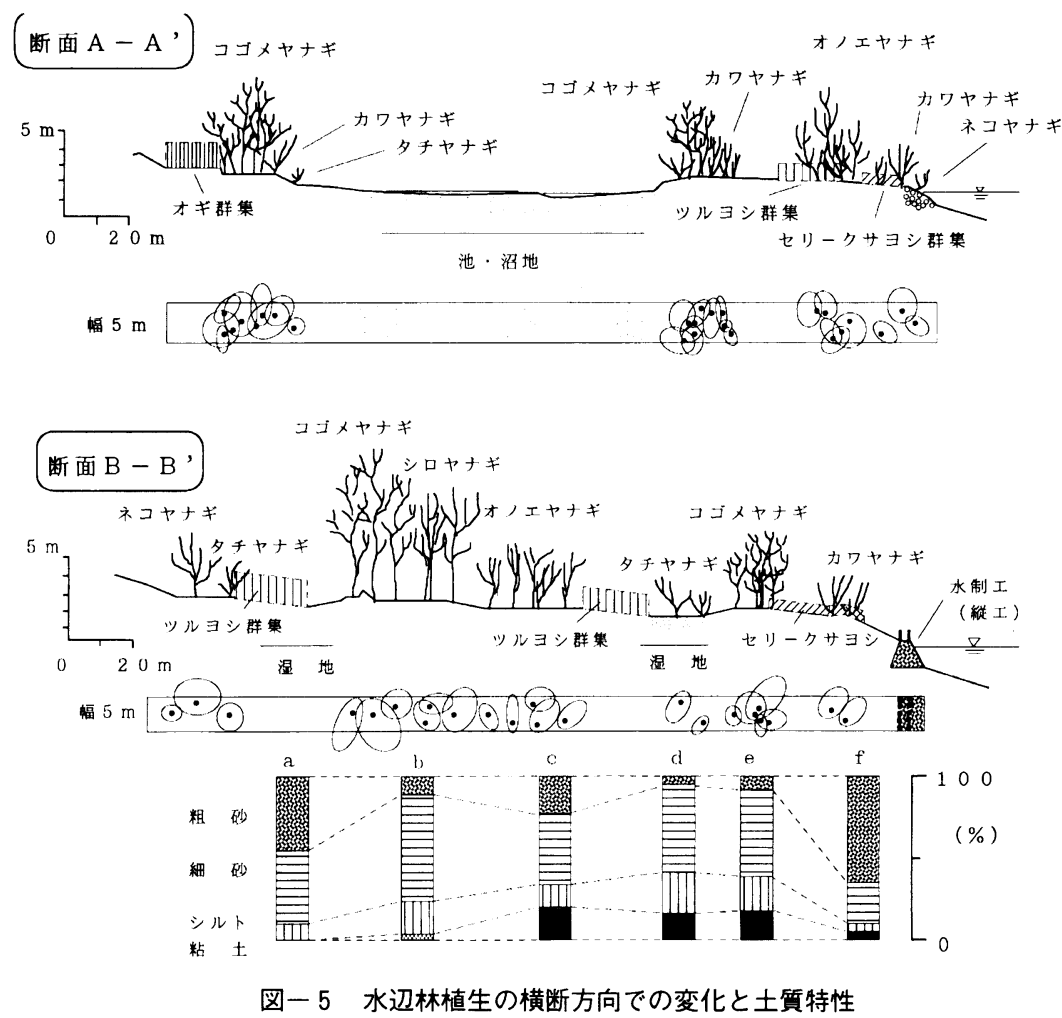

ナギやコゴメヤナギが生育していb 地点, c 地点, e 地点では 23～26\%と低いことがわ かる。したがって, 中州や干潟などの裸地が 出現すると，そこにはどの樹種も平等に侵入 を開始するが, 水縁部からの距離や比高, 形 状など微地形的な要因によって水分条件が異 なり、これがその後のヤナギの生育に影響を 及ほしていることが推測される。河口付近の
低湿地では，地下水位の高低がヤナギ類や八 ンノキ類の侵入後の生育に大きな影響を与え ていることが報告されている ${ }^{13)}$ が，当該区間 においても水縁部からの距離や比高, 微地形 が水分条件の違いとなり，これが前述の侵入 樹種の位置的な違いによる樹種の違いをもた らした要因のひとつであると考えられる。ま た, 侵入時期による樹種の違いは,こうした 
初期侵入の条件によるものではないかと思わ れる。これは草本類についても同様で, 冠水 しやすい湿地にセリークサヨシ群集が認めら れ, ツルヨシ群集はシルト・粘土がある程度 含まれるところに分布し，相対的にやや乾燥 する微高地にオギ群集が認められた。

杉山到 は, 地形や水分条件に扔ける多様さ を作り出すことが多様な生態系をもつエコパー ク造成の基礎であるとしているが, 水制域で は土砂沈殿の進行に伴って中州や干潟, 池 . 沼地, 湿地, 微高地など多様な微地形が形成 され時間とともに変化し，多様な土質特性や 水分条件をもたらし，これを基盤として多様 な生態系の母体となる植物空間が形成されて いると言えるであろう。換言すれば，水制域 では微地形が多様性を創出する大きな因子で あると言える。

\section{4. 水辺林形成の外的要因}

前述のように，当該区間では 1887〜1912 年間に行われた明治改修によって長良川と完 全に分流され水制工が施工されたが，この改 修以降，特筆すべき河川工事は行われていな い。従って, 1967 年以降急速に土砂堆積が進 行し水辺林が成立した要因として, 河川流量 や流入土砂量など外的要因の変化が考えられ る。ここでは, 建設省木曽川下流工事事務所 所管の起 (おこし) 観測地点 (約 $10 \mathrm{~km}$ 上流 地点)での観測值を当該区間への流入量と考 え，その変化を調べた。

近年での年間総流入量, 水制域が完全に冠 水する流量（冠水流入量； $1,000\left(\mathrm{~m}^{3} / \mathrm{sec}\right.$ ) 以 上の洪水流量の年総量), 年最大洪水流量の 推移は図一-6のように示される。ここでは, 流量の長期変動傾向が比較的顕著である 5 年 移動平均值で示した。これによると，年間総 流出量は 1963 年, 76 年, 83 年をピークとす る上下変動の繰り返しを示し, 最近では 1988 年に执いて観測期間での最小值となりその後 は増加の傾向を示しているが, 期間を通じて の大きな変動は見られず，当該区間において 毎年平均的な流入量のあることを示している。 これに対して冠水流入量 $\left(1,000\left(\mathrm{~m}^{3} / \mathrm{sec}\right)\right.$ 以 上の年間総量) の推移は, 1976 年頃と 1985 年頃をピークとし約 10 年を一つのサイクル とする上下変動を繰り返しながら, 1963 年 以降漸次的な減少傾向にあることが認められ た。この $1,000\left(\mathrm{~m}^{3} / \mathrm{sec}\right)$ という流量は, 当 該区間では水深が約 $5 \mathrm{~m}$ に相当するもので, 水制域が確実に冠水する流量であり, その減 少傾向は先に示した河岸の微地形変化の過程 と一致しているのである。

一方，年最大流量の推移をみると，1963 年 以降漸次的な減少を示し 1981 年では 1963 年 の半分近くにまで減少した後, 1980 年代前 半には 1963 年の水準にまで増加するが 1986

表一 3 土質特性（断面 B - B'）

\begin{tabular}{|c|ccccccc|}
\hline 地 点 & $\mathrm{a}$ & $\mathrm{b}$ & $\mathrm{c}$ & $\mathrm{d}$ & $\mathrm{e}$ & $\mathrm{f}$ \\
\hline 含水比 (\%) & 35.2 & 25.6 & 23.0 & 40.1 & 25.5 & 17.5 \\
\hline $\mathrm{p} \mathrm{H}$ & 6.7 & 6.3 & 6.4 & 6.5 & 6.2 & 6.6 \\
\hline $\begin{array}{l}\text { 電気伝導度 } \\
\mu \mathrm{S} / \mathrm{c} \mathrm{m}\end{array}$ & 37.5 & 64.2 & 39.5 & 32.0 & 50.4 & 55.5 \\
\hline
\end{tabular}

（1）年間流入量の推移比較 $\left(\times 10^{9} \mathrm{~m}^{3}\right)$

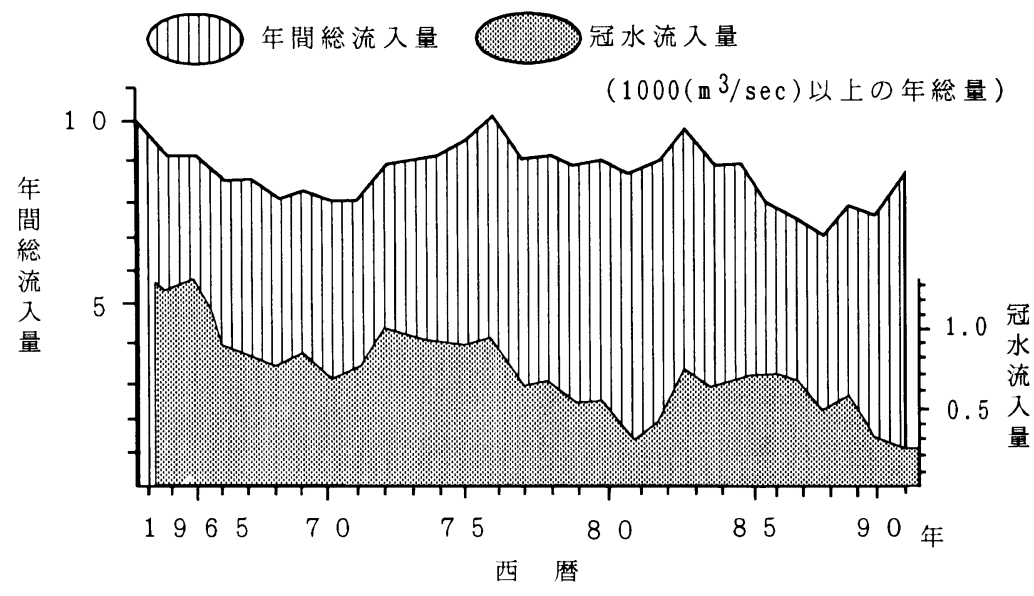

（2）年最大洪水流量の推移（m $3 / \mathrm{s}$ e c ）

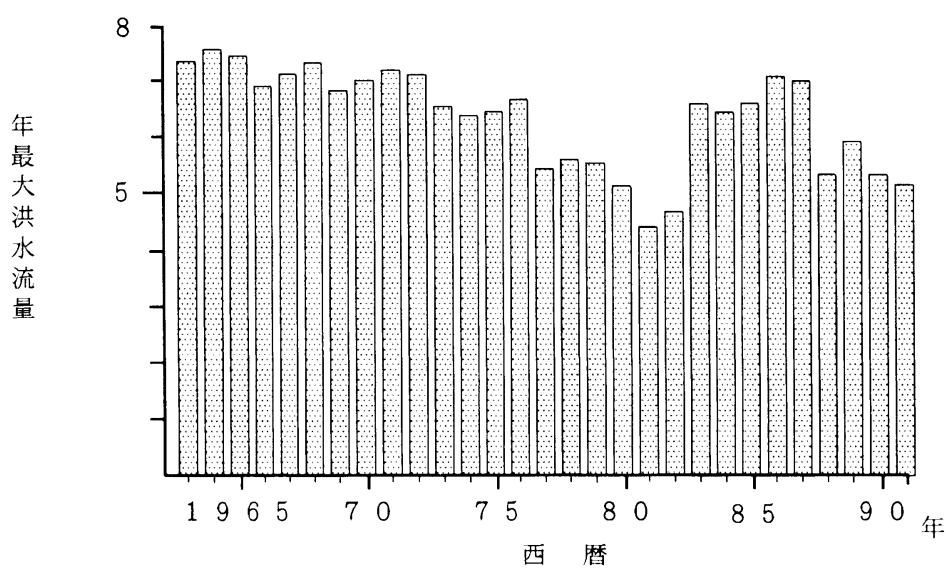

図一 6 水制域への流入量の推移（ 5 年移動平均值）

年以降再び減少している。また, 1932 年（昭 和 13）洪水では約 $40 \mathrm{~km}$ 上流の今渡地点にお

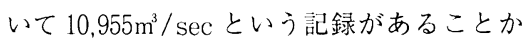
ら，当該区間にはこれを上回る規模の流入が あったことが確実であり，その後 1980 年代 前半は一時增加した時期があったものの, 土 砂堆積が促進され植生侵入が進んだと考えら れる1970年代後半までの期間では漸次的に 滅少している。

従って, 当該区間に扮いて 1967 年以降,
急速に土砂堆積が進行し水辺林が形成された 外的要因として, 年間総流量には大きな変動 は見られないものの，年最大洪水流量や水制 域が冠水する洪水流量の規模や頻度, および その総量の減少など流況の変化があったので あり,これは洪水ピーク流量の低減など洪水 形態が変化したことを意味している。

すなわち, この木曽川下流部の水制域内に 造られた見事な水辺林は, 上流に展開された 洪水刘策の効果に負うところが大きいと考え 
られ，これは換言すれば，河川流域をひとつ の水系としてとらえた場合，上流においてあ る水準で洪水刘策・土砂対策がなされていれ ば,下流の平地河川に扔いては護岸部を画一 的にコンクリートで固める必要はなく, 生物 空間を許容しうる手法を用いることが可能と いうことである。

\section{5. 水辺環境の復活と造園の役割}

1) 技術的可能性

河川改修など人為による水辺環境の改造の 行き着くところが水辺の単調化にあるとす机 ば, 水辺環境の復活とは, 水辺環境の多様性 をある水準に保つことに他ならない。砂防工 事や河川匹事の対象河川に扔いて多様性を保 つためには, 施設構造物が多様性創出に及ほ す影響を考慮し，自然の回復力を前提として 回復可能な領域をできるだけ河川に与えるこ $と^{(8)}$ が技術の前提として必要である。護岸部 をコンクリートで固めるといった場の固定や 過度な施設投資によっては,こうした多様性 は失われることになるが，災害防止との接点 から適切な施設を適切に配置すれば，多様性 をある水準で維持できると思われる。自然状 態にある河川と同様に，構造物が造られた半 白然的な河川も, 正しく評価する必要があり, こうした構造物との有機的な連携のもとで造 園技術を適用することが，それぞれの機能を 十分に発揮させることにもなる。以下に，今 回の調查によって得られた技術的可能性を述 ベる。

水辺など, 河川敷への木本類の植栽は, 洪 水時における河川の疎通能力に支障をきたす ものとして, 許容されてはこなかったが, 植 栽基準の見直しが行われ，近年ではこれまで よりは広い籁囲で植栽が許可されるようになっ た。そして, 現在の河川敷地の植生管理では,

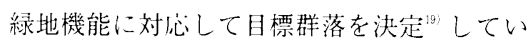
る。

これ江対し，水制域で成立する水辺林は， 土砂沈澱の促進によって堤防・河岸を保護す るという水制工の効果の発現過程の中で, 中 州や干潟, 池・沼, 湿地, 微高地などの微地 形が形成され，その水分条件の違いによって 自然立地的に成立する多様な植物空間である。 さらに，微地形は土砂沈澱の進行とともに $($ 干潟 $) \rightarrow($ 池 - 沼 $) \rightarrow($ 湿地 $) \rightarrow($ 乾燥地 $)$ へと時間的に変化し，これによって群集やヤ ナギの種類も変化することになる。

植物など生きもの技術を取り扱う場合，生 物社会が常に生長し変化するものであること や, 土木行為と生物社会との時間軸の不一 致8)など, 時間スケールが明確でないために, 施丁.後の維持管理に支障のあることが指摘さ れている。沢畑 ${ }^{16}$ は完成時の形態から保全系 樹林を修景林 - 環境保全林 - 防災林 - 環境林
に区分し，それぞれ造園的・生態的・防災的・ 環境的手法の必要性を述べているが, この指 摘と同様に河川植生の維持管理についても河 川空間をそれ自体でひとつの生態的まとまり としてとらえ, 時間の進行に忍じて人工的 半白然的 $\rightarrow$ 自然的植栽へと段階的に適切な維 持管理を行うという, 弾力的な計画が必要で あると思われる。

具体的には周辺の土地利用との関連も考慮 しなければならないことであるが, 植物群落 やそこに生息する昆虫・動植物の内容（貴重 さ）などに応じて， a. 人間の立ち入りを禁止すべき空間
b. 保全対象に応じた対策を施す空間
c.人間の利用をある程度䘜める空間 に区分し，段階（時間経過）に心じて自然環 境復元の技術 ${ }^{18}$ を適用すればよいと思われる。

なお，水辺に成立するヤナギ林は，低水護 岸としての機能の他, 魚類の生息条件や鳥類 相の生息空間を確保する゙ためにも貴重であ るが, 治水上の配慮から, 本川の水縁部では 高木性の木本は排除しなければならない。今 回の木曾川下流部での事例では, 水縁部には 夕チヤナギやネコヤナギなど, 低木性のヤナ ギが多く生育していたが, カワヤナギやキヌ ヤナギ,才ノエヤナギなど中一高木性のヤナ ギが一部干潟で認められ, また, 夕チヤナギ にも樹高の高くなるものが恝められたので, 高木性のものは除伐・間伐する必要があると 思われる(図一7)。

造園技術と砂防・河川技術によって得られ た安定空間を, 動的白然の䜑識の場として平 常時に人々に開放亦ることによって, 災害の 恐ろしさや自然への理解と共通認識が生まれ, 造園行為に対する理解が得られるものと考え る。

\section{2 ) 水辺環境復活于法の地域性}

土砂災害や水害は, 山崩れや土石流, 異常 出水などの白然現象が, 人間の社会活動が営
まれている地域で発生し, 生産行為・経済行 為に大きなダメージをもたらすものである。 従って, 地質や地質構造, 地形, 植生など自 然現象を生起しうる自然的要因と社会的要因 が地域によって異なれば, 災害現象, および, それを防ぐ砂防手法, 河川手法にも地域性が あるということになる。

本論で取り上げた河川工法である水制工は, 河川の底質や洪水時間, 水深, 勾配, 流速な どの河状特性を勘案して, 材料や形状など各 地で諸々の工夫がなされ, 各地で独自の発展 をとげてきたものである゙ 。従って，急流 河川に適用可能なものもあれば, 緩勾配区間 でその効果を発揮するものがあり，例えば， 木曾川下流では大きな効果をもたらしたケレッ プ水制も, 千曲川や天竜川などの急流河川で は流出し機能しなかった2!。これは川岸に水 辺林や入り江, 池・沼など多様な空間を復活 させる河川工法として注目される水制工であ るが, 施工筒所, 方法, 種類などがその河状 特性に適当でないと，十分な機能は発揮せず， 局所洗掘など周辺地域に大きな影響を及ぼす ことにもなりか杖いものであることを意味 している。

また逆に，水系上流で行われた洪水対策に よって下流の洪水流量が低減した結果, 木曽 川下流部の水制工の効果が現われたことから 明らかなように, 水制工の効果発現を左右す る河状特性は，上流での土砂対策や洪水対策 などによってある程度改造することも可能で ある。従って, 現況での治水対策の進渉状況 もいわばひとつの地域性を示すものととらえ ることができる。これらを指標として，用い るべき水制工の種類・規模等を検討しなけれ ばならない。

昨今, 人間と川とのかかわりをテーマに， 流域文化の保存という観点から河川環境が議 論されることがある。地域を支配する土地自 然に根ざしたものが流域文化であるとするな
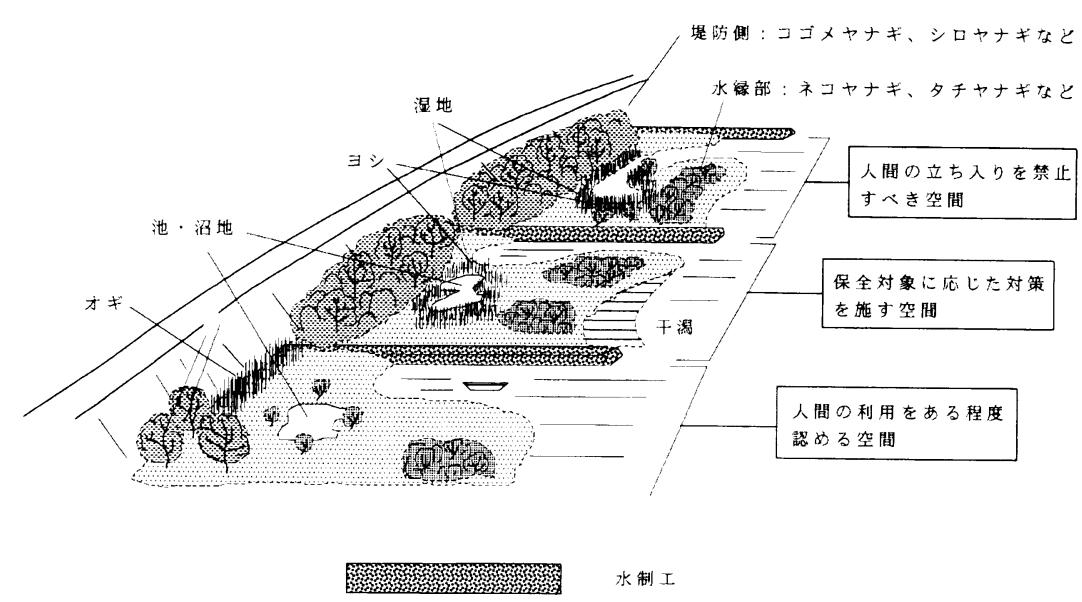

図-7 水制域の水辺林の維持管理（概念図） 
ら，流域文化に培われた保全思想・保全技術 にも地域固有のものがある。画一的な考え方 と技術を日本各地に展開するのではなく，土 地自然の地域性を認識し, 流域文化を反映し うるような環境保全システムを確立すること が，国土利用に対する視点が多様化した現在 において急務であると思われる。

\section{おわりに}

水辺環境保全をめぐる問題は，広く一般の 人々の関心を呼ぶところとなり, 水辺環境復 活のための具体的な検討が日本各地で行われ ている。その中で, いわゆる生きものにやさ しい河川工法として近自然河川工法 ${ }^{3}$ が注目 を集め, 実河川への適用が試みられている。 わが国では伝統的な河川工法の復活など，用 いるべき手法のみが話題となりがちであるが, 近白然河川工法とは, 本来, 景域保全的視野 に基づいた河川改修の技術であり，その背景 には，河川の上流から下流まで流域全体を広 くとらえた綿密な治水対策の検討がベースと して存在していることを忘れてはならない。 それは, 洪水防御のためにはどのような方策 をとるべきか十分な検討を経たうえでの，河 川技術者, 生物学者, 景観工学者の共同作業 による水辺維持計画なのである。

河状特性が異なるわが国においては, 空間 処理の考え方" に基づき, 土砂対策や洪水対 策をなすべき土砂処理空間と洪水調節空間, 積極的に自然を保全すべき近自然空間を設定 し，おのおの復活すべき自然の内容や水準に 応じて造園技術を導入し, 水辺環境を復活す ることが有効ではないかと思われる。

本論で対象としたのは, 砂防工事や河川工 事が流域の安定化には不可欠な荒廃河川であ り, 純然たる自然環境が残されている清流で
はない。すべての河川に同様な技術を画一的 に適用するのではなく，白然河川が希少になっ た現在，自然が保たれている渓流は近自然空 間として位置づけ，積極的に保護すべきであ り，やむなく砂防工事や河川工事を行う場合 でも必要最小限に止めておくことが水辺環境 の保全になる。

最後に, 本研究は一部, 河川環境管理財団 による河川整備基金助成金を使用したもので あることを付記する。

\section{引用・参考文献}

1 ) 赤井 裕 (1992): 希少魚類の絶隇防止 と今後の保護管理：環境研究 $85,49-$ 56.

2 ）安芸咬一 (1952) : 河川工学 : 1-186, 共 立出版株式会社

3）クリスチャン・ゲルデイ・福留修文 (1990) : 近自然河川工法 : 1-99, 近自然 河川工法研究会

$4 ）$ 土質工学会編 (1979)：土質試験法：1757, 土質工学会.

5 ) 東 三郎 (1979)：地表変動論一植生判 別による環境把握 : 1-280, 北海道大学 図書刊行会

6 ）東三郎（1983）：石れき指標に関する 砂防学的研究: 北海道大学農学部演習林 研究報告 40-1，197-232.

7 ) 井手久登：竹内和彦（1985）：自然立地 的土地利用計画 : 1-227, 東京大学出版 会.

8 ) 龟山 章·勝野武彦 ·養父志乃夫 - 倉本 宣（1992）：生きもの技術としての造 園一その 5 生きもの技術の技術化: 造 園雑誌 56(3)，259-265.

9 ) 建設省編 (1990)：日本の河川：1-630
社団法人建設広報協議会

10）建設省静岡河川工事事務所（1988）：安 倍川砂防史, 1-399.

11）北村秦一（1990）: 変動流域の総合利用 に関する砂防学的研究：南九州大学園芸 学部研究報告 $20,1-65$.

12）北村泰一（1992）：床固工群による渓流 の水辺環境保全に関する考察：新砂防 45(1), 3-13.

13）岡村俊邦 (1991)：河畔林の再生に関す る砂防学的研究: 平成 3 年度砂防学会研 究発表会概要集, 196-199.

14）坂口 豊·高橋 裕 · 大森博雄 (1986): 日本の川：日本の自然 $3 ， 1-248$, 岩波 書店.

15）桜井善雄（1991）: 水辺の環境学 : 1-222, 新日本出版社。

16）沢畑浩（1990）：北海道における環境 林造成計画に関する基礎的研究：造園雑 誌 54(1), 43-50.

17）杉山恵一（1992）：自然環境復元入門：1212, 信山社出版株式会社.

18）杉山恵一・進士五十八編（1992）：自然 環境復元の技術 : 1-170, 朝含書店.

19）高橋理喜男·龟山 章 (1987)：緑の景 観と植生管理 : 1-241, 株式会社ソフト サイエンス社.

20）安田伸生（1978）：砂防技術による水辺 環境整備に関古る研究: 北海道大学農学 部修士論文, 1-114.

21）財団法人日本ダム協会（1991）：ダム年 鑑 $1-1260$

22）財団法人リバーフロント整備センター編 （1992）：まちと水辺に豊かな自然をII： $1-185$, 山海堂.

(1993. 7.24 受付, 1995.1 .28 受理)

Summary : Japan has frequently experienced natural disasters because of special geological condition. Recently, disasters caused by floods and deblis flows have killed many people and involved great property loss. Therefore, development plans in areas of high erosion susceptibility should make provisions for flood and erosion control. At the same time, deterioration of riparian environment caused by civil engineering works is being seen, and warnings against limited diversity of river have been repeatedly heard. Landscape techniques can be indispensable to restore riparian environment, thus the purpose of this study is to present new technical ideas to improve riparian environment with landscape techniques associated with erosion control.

It is shown by photointerpretation and ground survey that using a series of groins suits with the characteristics of river basins for flood control on gentle slope section of tidal river,the diverse area consisting of several microtopographies are designed on the riparian zone. These area such as tidal flats, channel bars, and marsh play a significant role in preservation of various riparian ecosystem. Therefore, it can be recommended for regeneration and preservation of riparian environment that erosion control techniques which have no negative effect on uniqu riparian environment, such as groyne works, can be arranged, and that the structure, function, and dynamics of landscapes should be altered by design subsequently. 